Acta Universitatis Lodziensis

\title{
Virological aspects of non-human primates or swine-to human xenotransplantation
}

\author{
Natalia MaZUrkiewiCZ ${ }^{1 *}$, AgnieszKa NowaK ${ }^{1}$, Magdalena HryHorowicz ${ }^{1}$, \\ JOANNA ZEYLAND ${ }^{1}$, DANIEL LIPIŃSKI ${ }^{1}$, RYSZARD SŁOMSKI ${ }^{1,2}$ \\ ${ }^{1}$ Department of Biochemistry and Biotechnology, Poznan University of Life Sciences, ul. Dojazd 11, 60- \\ 632 Poznań \\ ${ }^{2}$ Institute of Human Genetics of Polish Academy of Sciences, ul. Strzeszyńska 32, 60-479 Poznań \\ E-mail: nmmazurkiewicz@gmail.com
}

\section{AbSTRACT}

There are a number of human diseases, which can lead to organ failure. The consequence is often the need for a transplant. The number of performed operations is very low due to the shortage of organs for transplantation. As a consequence, the number of people waiting for transplant is still growing. The solution to this situation may be xenotransplantation. Xenotransplantation word comes from the Greek xenos meaning stranger, the other. It is defined as any procedure that involves the transplantation, implantation or infusion of tissues or zoonotic organs into a human recipient, but also human body fluids, cells, tissues, organs (or fragments) that have ex vivo contact with zoonotic cells, tissues or organs. One of the obstacles of the xenograft transplantation is the risk of animal pathogens transmission to the humans. Viruses that pose risk in the non-human primates-to-human xenotransplantation includes: the human immunodeficiency virus - HIV and the Marburg virus described in this paper. In addition viruses, which is a problem in pig-to-human xenotransplantation have also been described, including: porcine endogenous retrovirus - PERV, porcine cytomegalovirus - PCMV, porcine lymphotropic herpesvirus - PLHV and hepatitis E virus - E - HEV. This review of literature is the latest knowledge of the microbiological safety of xenotransplantation.

KEY WORDS: PERV, HIV, zoonoses, transgenic animals

\section{Introduction}

Transplantation involves the removal of an organ, tissue, or cells from the donor's body and implantation into the recipient's body. The field of science that deals with the subject of an organ transplantation is transplantology. The organs are transplanted to recipients, whose do not have fully functioning organs due to the illness or mechanical damage. Transplantation of organs or its fragments is a life saving method that improves quality and prolongs lives of 
people for which there is no other treatment available (Smorąg et al. 2011, Saxena et al. 2016). We can distinguish four types of transplantations:

- autotransplantation - a transplantation within the body of the same person, an example may be transplanting skin from one place to another,

- allotransplantation - a transplantation between representatives of the same species, for example kidney transplantation between two people,

- isotransplantation - a kind of allotransplantation that is carried out between individuals with same genotype, for example monovular twins,

- xenotransplantation - a transplantation between individuals belonging to different species; an example is the transplantation between a pig and a human (Gołąb \& Basak 2012, Saxena et al. 2016).

Many human diseases can lead to organ failure. The consequence is often the need for a transplant. The number of the performed operations is very low due to the shortage of organs for transplantation. Therefore, the number of people waiting for transplant is still growing (Saxena et al. 2016). The way out of this situation may be xenotransplantation. The concept of organ transplantation in a pig-to-human or nonhuman-primate-to-human system is designed to keep the patient alive. Xenotransplantation research focuses on obtaining animals whose organs can be transplanted until a suitable human donor is found and ultimately to replace the human organs as a functionally and physiologically equivalent (Zeyland et al. 2015, Jura et al. 2006).

Xenotransplantation is defined as any procedure that involves the transplantation, implantation or infusion of tissues or zoonotic organs into a human recipient, but also human body fluids, cells, tissues, organs (or fragments) that have ex vivo contact with zoonotic cells, tissues or organs. There is a fundamental problem here, because of the presence of species specific antigens on the animals cells surface that are not present on the human cells. This incompatibility causes the side effects of transplantation of cells, tissues or organs from unmodified animals. It is a severe immune response that results in immediate or chronic rejection of the transplant (Cooper et al. 2015, Zeyland et al. Słomski 2015).

Since xenotransplantations have been considered as a viable option for dealing with the deficiency of organs required for transplantation to all people on the waiting lists, primate monkeys were tested as the most suitable animals. This choice was made because the non-human primates are closely related phylogenetically with humans. What is the biggest advantage of such a solution is its biggest disadvantage at the same time. Viruses that infect primates can infect humans as well. This is one of the factors that has determined the change of the subject matter of the research from primates to cloven-hoofed animals (especially pigs) (Smorąg et al. 2011, Jura et al. 2006, Cooperet et al. 2015).

\section{Virological risks in the nonhuman primates - to - human xenotransplantation}

The first animals that were taken into account in the context of xenotransplantation are primates. Apart from the obvious advantages of these animals associated with physiological similarity, they also have drawbacks, including one that limits the development of research in this direction. This obstacle is the virological risks. An example of a virus that has been transmitted from this animals to human and could be a problem in xenotransplantation is the human immunodeficiency virus - HIV. HIV is a lentivirus (a subgroup of retrovirus) that 
causes HIV infection. It causes an acquired immunodeficiency syndrome (AIDS) (Specke et al. 2002, Boneva et al. 2001).

Human immunodeficiency virus is transmitted by exchange or contact with body fluids of the host. HIV causing AIDS is one of the major pathogens - the sixth leading cause of mortality in the world. The life expectancy of people infected with HIV has increased over the years and is approaching the average in the population. This is the result of the efficacy of antiretroviral therapy (ART). The use of ART drugs has improved the quality of life of infected people and reduced morbidity and mortality (Rumbwere et al. 2016).

There are several strains of the virus that cause AIDS as a result of the human infection. The HIV-1 strain is derived from chimpanzees (Pan troglodytes) and its predominance is restricted to the inhabitants of Europe and America. The HIV-2 strain is derived from the sooty mangabey (Cercocebus atys) and is found predominantly in the populations of central Africa. HIV attacks the cells which have CD4 (clustered differentiation 4) receptors and also the cells with coreceptors CXCR4 or CXCR5 (C-X-C Chemokine receptor type 4 or 5 ) on their surfaces. HIV infection causes AIDS that develop by reducing the number of lymphocytes in the blood and thus weakening of the immune system. The death of a viral carrier is the result of infection with pathogens that a properly functioning immune system would be able to fight. HIV is one of the most variable viruses that precludes the immune system from fighting infection by producing the right antibodies, and makes it difficult to develop antiviral drugs and vaccines (Boneva et al. 2001, Rumbwere et al. 2016).

Another virus, which is a problem in non-human primates-to-human xenotransplantation is the Marburg virus, which belongs to the Filoviridae family. This virus was transferred to a man from the green monkey (Chlorocebus sabaeus). The Marburg virus genome is singlestranded nonsense RNA (-ssRNA). It causes a disease called haemorrhagic fever which is very difficult to treat. The virus can be transmitted through contact with an infected person, or it can be transmitted via droplet path (Günzburg \& Salmons 2000).

Viruses, which pose a direct threat in non-human primates-to-human xenotransplantation are very numerous, and combating them has not produced measurable results so far, so the researchers left the concept of using primates for xenotransplantation. (Cooper et al. 2015).

\section{Virological risks in the pig - to - human xenotransplantation}

An animal that seems to be more suitable for use in xenotransplantation is the domestic pig (Sus scrofa domestica). Despite the phylogenetic remoteness of the pig from human, the functionality of its organs and size is similar to human organs. However, despite of the fact that the virological problem in this xenotransplantation system is smaller, it also worries the researchers (Fischer et al. 2016). The pig is a carrier of the porcine endogenous retrovirus - PERV. This is the biggest problem because of the integration of the viral genome into many loci of the pig genomes. PERVs are the acquired elements that are present in the majority of the pig genomes. What is more, PERV like other retroviruses often recombine and it is able to "transposing" in the pig genome as transposon. It also has the ability to recombine with human retroviruses. This recombination is a big problem, as it can lead to the uprising of the virulent strains of viruses that will be 
unpredictable. PERV provirus sequences have been classified as A, B, and $\mathrm{C}$ types, where $\mathrm{A}$ and $\mathrm{B}$ are predominantly present in the genome of all pigs, while the presence of type $\mathrm{C}$ is strongly reduced or absent (Plotzki et al. 2015). A transmission of porcine endogenous retrovirus type $\mathrm{A}$ and $\mathrm{C}$ recombinants to human cells in vitro has been observed. But the presence of these recombinants in the genome of the pig in vivo has not been proven. In addition, the virus is only capable of infecting human cell lines in vitro. However, the transfer of the virus from pig to human was not observed in vivo (Wilson 2008, Scobie \& Takeuchi 2009). This may be related to the fact that human cells have many mechanisms to fight viral infections. In particular, a group of proteins capable to combating viral infections called: apolipoprotein B mRNA-editing catalytic polypeptide cytidine deaminases - APOBEC. The expression of these proteins in transgenic animal cells could reduce the PERVs potential infection and thereby protect patients after xenotransplantation (Dörrschuck et al. 2008). The complement lysis system can also protect cells from infection with the porcine endogenous retrovirus. This suggesting that there is no evidence of infection with this virus in vivo, which may be caused by the human-host immune system (Fujita et al. 2003). It should be noted that the mechanism will be no longer effective in animals with a knock-out of the gene encoding $\alpha-1,3$ galactosyltransferase (Gal-KO animals), so some of the concerns may involve the use of animals with this modification (Kuwaki et al. 2005). Therefore, PERV provirus genes should be eliminated from the pig genome. Due to the large number of components of the PERVs in the swine genome this seemed to be impossible. However, endogenous pig retroviruses were inactivated in 2015 using the
CRISPR/Cas9 system. In experiments, the complete inactivation of all the identified genome provirus copies in one individual has been achieved. There were as many as 62 copies of the virus. For this purpose, specific gRNA was designed that was complementary to the very conservative catalytic center of the pol gene present in the sequences of each type of PERVs. This gene encodes the protein that acts as a reverse transcriptase and is essential for proper replication and virus infection (Yang et al. 2015). This is a huge success that brings researchers closer to completely eliminating the PERVs problem in xenotransplantations. However, these are not the first successes in the study of the PERV virus in this aspect. Earlier attempts were made to inactivate porcine endogenous viruses with siRNA silencing mechanism with very good effects, but not as spectacular as in the case of application of the CRISPR/Cas9 system (Dieckhoff et al. 2008, Yang et al. 2015).

The second virus, which can be a problem in pig-to-human xenotransplantation is porcine cytomegalovirus - PCMV. It belongs to the herpesvirus family. Studies in the pig-to-non-human primates xenotransplantation have shown an increased replication of PCMV in transplanted tissues due to immunosuppression (Morozov et al. 2017). In addition, it has been shown that enhanced replication leads to damage of the endothelial cell layers and the massive coagulopathy, which in turn can accelerate the process of the xenograft rejection. However, no transfer of the virus from swine transplanted tissues to non-human primates tissues has been reported. Additional studies indicate the susceptibility of human fibroblast in vitro cultures to PCMV infection and decreased susceptibility to antiviral drugs used in CMV cytomegalovirus therapy. An 
effective way of eliminating this virus is the early withdrawal of piglets from the sow. This appears to be sufficient in the context of the use of these animals in xenotransplantations (Gollackner et al. 2003, Morozov et al. 2016).

The third swine virus posing a problem in xenotransplantation is the porcine lymphotropic herpesvirus PLHV. There are three types of this virus: 1,2 and 3 . It belongs to the $\gamma$-herpesvirus family. This virus is homologous to the human herpesvirus $8-\mathrm{HHV}-8$ (otherwise known as Kaposi's sarcoma-associated herpesvirus - KSHV or Epstein-Barr virus - EBV) (Plotzki et al. 2016). Although transmission of the PLHV from pig to non-human primates tissues has not been shown after xenotransplantation. The high PLHV homology with human HHV-8 and EBV viruses may induce PLHV-1 activation after recombination, which was observed experimentally (Gazda et al. 2016). No effective method of controlling this virus was found, only the monitoring of swine breeding is suggested (Santoni et al. 2006, Morozov et al. 2016).

The next virus posing a problem in the pig-to-human xenotransplantation is hepatitis E virus (HEV). This type of virus (subtype 1 precisely) occurs in tropical and subtropical climates. A human can get infected with this virus by drinking water contaminated with animal manure. In recent years, there has been an increase in the number of infected with subtype 3 of this virus, which is common in pigs. The infection occurs also during allotransplantation or by ingestion of infected pork. This direct mechanism of infection makes the virus one of the major problems of xenotransplantation at the moment (Banks et al. 2004, Morozov et al. 2016).

Despite the wide variety of pig viruses potentially endangering the human health after xenotransplantation, it has not been proven that such infections would be possible in an in vivo system. The exception is the hepatitis E virus, but it can be prevented by keeping the appropriate conditions for animals and regular veterinary testing (Onions et al. 2000).

\section{Summary}

The modern transplantology problem of insufficient quantity of tissues and organs for transplantation is increasingly alarming. Statistics show that more and more patients are waiting for organs. The solution to this urgent problem could be xenotransplantation (Saxena et al. 2016).

After many years of comprehensive research on non-human primates-tohuman xenotransplantation, the attention has been placed on another animal - the domestic pig. The change in concept was dictated primarily by the very high risk of transmitting viruses from primates. Viruses from non-human primates that threaten humans includes human immunodeficiency virus (HIV) or Marburg virus. These are not the only viruses that could be a problem in xenotransplantation. There is a high likelihood of infection with viruses that have not yet been reported in humans and appears in non-human primates. This threat is due to the high phylogenetic proximity of humans and primates. Moreover, there are no effective methods to preventing these infections or their effective treatment.

Hence the change in the direction of xenotransplantation and the interest in the domestic pig. The great advantage of this animal is the functionality and size of its organs, which is similar to human organs. However, the topic of threat to zoonoses also exists in this case. Although viruses that may be a problem in pig-to-human xenotransplantation have been also described, but in most cases this is a hypothetical threat that has 
not occurred in vivo. The viruses described in the context of pig-to-human xenotransplantation includes porcine endogenous retrovirus - PERV, porcine cytomegalovirus - PCMV, porcine lymphotropic herpesvirus - PLHV and hepatitis $\mathrm{E}$ virus (E-HEV). However, there are effective methods for eliminating all of the above viruses and others can be excluded by genetic engineering or maintaining appropriate conditions for animals and regular veterinary examinations.

\section{Acknowledgements}

Presented work was financially supported by The National Centre for Research and Development (grant number INNOMED/I/17/NCBR/2014) from the Innovative Economy Operational Programme founds, in the framework of the European Regional Development Fund.

\section{References}

Banks, M., Bendall, R., Grierson, S., Heath, G., Mitchell, J., Dalton, H. 2004. Human and porcine hepatitis $\mathrm{E}$ virus strains, United Kingdom. Emerging Infectious Diseases, 10 (5): 953-955.

Boneva, R., Folks, T., Chapman, L. 2001. Infectious disease issues in xenotransplantation. Clinical Microbiology Reviews, 14 (1): 1-14.

Cooper, D.K.C., Ekser, B., Tector, J. 2015. A brief history of clinical xenotransplantation. International Journal of Surgery, 23: 205-210.

Dieckhoff, B., Petersen, B., Kues, W.A., Kurth, R., Niemann, H., Denner, J. 2008. Knockdown of porcine endogenous retrovirus (PERV) expression by PERV-Specific shRNA in transgenic pigs. Xenotransplantation, 15 (1): 36- 45 .

Dörrschuck, E., Münk, C., Tönjes, R.R. 2008. APOBEC3 proteins and porcine endogenous retroviruses. Transplantation Proceedings, 40 (4): 959-961.

Fischer, K., Kraner-Scheiber, S., Petersen, B., Rieblinger, B., Buermann, A., Flisikowska, T., Flisikowski, K., Christan, S., Edlinger, M., Baars, W., Kurome, M., Zakhartchenko, V., Kessler, B., Plotzki, E., Szczerbal, I., Switonski, M., Denner, J., Wolf, E., Schwinzer, R., Niemann, H., Kind, A. Schnieke, A. 2016. Efficient production of multi-modified pigs for xenotransplantation by 'combineering', gene stacking and gene editing. Nature Scientific Reports, 6: 29081.

Fujita, F., Yamashita-Futsuki, I., Eguchi, S., Kamohara, Y., Fujioka, H., Yanaga, K., Furui, J., Moriuchi, R., Kanematsu, T., Katamine. S. 2003. Inactivation of porcine endogenous retrovirus by human serum as a function of complement activated through the classical pathway. Hepatology Research: The Official
Journal of the Japan Society of Hepatology, 26 (2): 106-113.

Gazda, L. S., Collins, J., Lovatt, A., Holdcraft, R.W., Morin, M.J., Galbraith, D., Graham, M. Laramore, M.A., Maclean, C., Black, J., Milne, E.W., Marthaler, D.G., Vinerean, H.V., Michalak, M.M., Hoffer, D., Richter, S., Hall, R.D., Smith, B.H. 2016. A comprehensive microbiological safety approach for agarose encapsulated porcine islets intended for clinical trials. Xenotransplantation, 23 (6): 444-463.

Gollackner, B., Mueller, N.J., Houser, S., Qawi, I., Soizic, D., Knosalla, C., Buhler, L., Dor, F.J., Awwad, M., Sachs, D.H., Cooper, D.K., Robson, S.C., Fishman, J.A. 2003. Porcine cytomegalovirus and coagulopathy in pig-toprimate xenotransplantation. Transplantation, 75 (11): 1841-1847.

Gołąb, J., Basak, G.W. 2012. Immunologia. Wydawnictwo Naukowe PWN, Warszawa.

Günzburg, W.H., Salmons, B. 2000. Xenotransplantation: is the risk of viral infection as great as we thought? Molecular Medicine Today, 6 (5): 199-208.

Jura, J., Słomski, R., Gajda, B., Wieczorek, J., Lipiński, D., Kalak, R., Juzwa, W., Zeyland, J. 2006. Uzyskiwanie świń wykorzystywanych w ksenotransplantacji. Biotechnologia, 1 (72): 151-158.

Kuwaki, K., Tseng, Y.-L., Dor, F.J.M.F., Shimizu, A., Houser, S.L., Sanderson, T.M., Lancos, C.J., Prabharasuth, D.D., Cheng, J., Moran, K., Hisashi, Y., Mueller, N., Yamada, K., Greenstein, J.L., Hawley, R.J., Patience, C., Awwad, M., Fishman, J.A., Robson, S.C., Schuurman, H.J., Sachs, D.H., Cooper, D.K. 2005. Heart transplantation in baboons using $\alpha 1,3$-galactosyltransferase gene-knockout pigs as donors: initial experience. Nature Medicine, 11 (1): 29-31. 
Morozov, V.A., Plotzki, E., Rotem, A., Barkai, U., Denner, J. 2016. Extended microbiological characterization of göttingen minipigs: porcine cytomegalovirus and other viruses. Xenotransplantation, 23 (6): 490-496.

Morozov, V.A, Heinrichs, G., Denner, J. 2017. Effective detection of porcine cytomegalovirus using non-invasively taken samples from piglets. Viruses, 9 (1): 1-14.

Onions, D., Cooper, D.K., Alexander, T.J., Brown, C., Claassen, E., Foweraker, J.E., Harris, D.L., Mahy, B.W., Minor, P.D., Osterhaus, A.D., Pastoret, P.P., Yamanouchi, K. 2000. An approach to the control of disease transmission in pig-to-human xenotransplantation. Xenotransplantation, 7 (2): 143-155.

Plotzki, E., Wolf-van Buerck, L., Knauf, Y., Becker, T., Maetz-Rensing, K., Schuster, M., Baehr, A., Klymiuk, N., Wolf, E., Seissler, J., Denner, J. 2015. Virus safety of islet cell transplantation from transgenic pigs to marmosets. Virus Research, 204: 95-102.

Plotzki, E., Keller, M., Ehlers, B., Denner, J. 2016. Immunological methods for the detection of porcine lymphotropic herpesviruses (PLHV). Journal of Virological Methods, 233: 72-77.

Rumbwere, D., Benhildah, N., Marshall, T.P., Ryan, R.P. 2016. Predictors of human immunodeficiency virus (HIV) infection in primary care: a systematic review protocol. Systematic Reviews, 5 (1): 158.

Santoni, F., Lindner, I., Caselli, E., Goltz, M., Di Luca, D., Ehlers, B. 2006. Molecular interactions between porcine and human gammaherpesviruses: implications for xenografts? Xenotransplantation, 13 (4): 308 317.

Saxena, R., Khan, F., Masood, M., Qureshi, Z., Rathore, M. 2016. Review on transplantation: a social medical need. Journal of Critical Reviews, 3 (2): 1-7.

Scobie, L., Takeuchi, Y. 2009. Porcine endogenous retrovirus and other viruses in xenotransplantation. Current Opinion in Organ Transplantation, 14: 175-179.

Smorąg, Z., Słomski, R., Jura, J., Lipiński, D., Skrzyszowska, M. 2011. Transgeniczne świnie jako dawcy tkanek i narządów do transplantacji U Ludzi. Przegląd hodowlany, 11:1-4.

Specke, V., Schuurman, H.J., Plesker, R., Coulibaly, C., Ozel, M., Langford, G., Kurth, R., Denner, J. 2002. Virus safety in xenotransplantation: first exploratory in vivo studies in small laboratory animals and non-human primates. Transplant Immunology, 9 (2-4): 281-288.

Wilson, C.A. 2008. Porcine endogenous retroviruses and xenotransplantation. Cellular and Molecular Life Sciences, 65 (21): 3399-3412.

Yang, L., Guell, M., Niu, D., George, H., Lesha, E., Grishin, D., Aach, J., Shrock E., Xu, W., Poci, J., Cortazio, R., Wilkinson, R.A., Fishman, J.A., Church, G. 2015. Genome-wide inactivation of porcine endogenous retroviruses (PERVs). Science, 350 (6264): 1101-1104.

Zeyland, J., Lipiński, D., Słomski, R. 2015. The current state of xenotransplantation." Journal of Applied Genetics 56 (2): 211-218.

\section{Streszczenie}

Istnieje wiele chorób człowieka, które mogą doprowadzić do niewydolności narządów. Konsekwencją często jest konieczność przeprowadzenia przeszczepu. Liczba wykonywanych operacji jest bardzo niska ze względu na niedobór narządów do transplantacji. W konsekwencji liczba osób oczekujących na przeszczep ciągle rośnie. Wyjściem z tej sytuacji może być ksenotransplantacja. Pojęcie ksenotransplantacja pochodzi od greckiego xenos oznaczającego obcy, inny. Jest to każdy zabieg polegający na transplantacji, implantacji lub infuzji biorcy - człowiekowi - komórek, tkanek lub organów odzwierzęcych, również płynów ustrojowych, komórek, tkanek, narządów człowieka (lub ich fragmentów), które miały kontakt ex vivo z komórkami, tkankami lub organami zwierzęcymi. Jedną $\mathrm{z}$ przeszkód w przeszczepach ksenogenicznych jest zagrożenie przeniesienia patogenów zwierzęcych i zainfekowanie organizmu człowieka. Wirusami, które stanowią zagrożenie w przeszczepach, w układzie małpy naczelneczłowiek to między innymi: ludzki wirus upośledzenia odporności HIV (z ang. human immunodeficiency virus) i wirus Marburg, które zostały opisane w niniejszej pracy. Ponadto przedstawiono wirusy stanowiące problem w transplantacjach w układzie świnia-człowiek, czyli: endogennego retrowirusa PERV ( $\mathrm{z}$ ang. porcine endogenous retrovirus), wirusa cytomegalii świni PCMV ( $\mathrm{z}$ ang. porcine cytomegalovirus), wirusa limfotroficznego świni PLHV (z ang. porcine lymphotropic herpesvirus) oraz wirusa 
zapalenia wątroby typu E - HEV (z ang. hepatitis E virus). Niniejszy przegląd literatury stanowi najnowszy stan wiedzy na temat mikrobiologicznego bezpieczeństwa ksenotransplantacji. 